\title{
Biogas Production from Sheep Manure by a Simulated Underground Burial System Heated with Cascade-Controlled Solar Water Heated System, as an Indicator of Biomass Potential Contribution to Power Mix in Jordan
}

\author{
Bahieh M. Alma'atah, Ali I. Alzoubi, Taha M. Alkhamis* \\ Department of Chemical Engineering, Mutah University, Mutah, Jordan \\ Email: *alkhamis@mutah.edu.jo
}

How to cite this paper: Alma'atah, B.M., Alzoubi, A.I. and Alkhamis, T.M. (2021) Biogas Production from Sheep Manure by a Simulated Underground Burial System Heated with Cascade-Controlled Solar Water Heated System, as an Indicator of Biomass Potential Contribution to Power Mix in Jordan. Journal of Environmental Protection, 12, 125-140.

https://doi.org/10.4236/jep.2021.122009

Received: January 11, 2021

Accepted: February 23, 2021

Published: February 26, 2021

Copyright $\odot 2021$ by author(s) and Scientific Research Publishing Inc. This work is licensed under the Creative Commons Attribution International License (CC BY 4.0).

http://creativecommons.org/licenses/by/4.0/ (c) (i) Open Access

\begin{abstract}
This paper is aimed at exploring the potential of implementing biomass as one of the sources of energy in Jordan using a simulated underground burial system. A controlled solar energy heated system was employed to maintain the anaerobic bioreactor at $40^{\circ} \mathrm{C}$ (mesophilic range). Sludge and wastewater, from wastewater treatment plant, was used as a seeding material to activate bacteria. Production of biogas was observed after 3 days of incubation. On average, a total of 94 liters/sample were obtained at $25^{\circ} \mathrm{C}$ and atmospheric pressure. This amount of gas is equivalent to 258 liters $/ \mathrm{kg}$ (Standard Temperature and Pressure, STP) of sheep manure. The biogas average composition was $65 \%$ methane and $35 \% \mathrm{CO}_{2}$, and the retention time was 35 days. Control runs at room temperature did not produce appreciable amount of biogas within the 35 days of incubation. The potential of biomass was studied based on estimated sheep manure production for the period of 2010-2016 in Jordan. The results obtained from the designed process were used to estimate the biogas production indicating a promising process to produce biogas by a burial bio-waste system. Upon scale-up of this process, biomass from different sources can be processed within short residence time, which will result in appreciable reduction of land fill areas and significant production of biogas that will contribute to the energy power mix in a non-oil producing country, such as Jordan.
\end{abstract}

\section{Keywords}

Biogas, Sheep Manure, Bio-Waste, National Grid, Power Production 


\section{Introduction}

The utilization of new energy sources that have economic potential as well as being environmentally friendly have been discussed in several publications [1] [2] [3]. Renewable energy is an important energy resource, which can contribute to the overall energy requirements of the world [4] [5] [6] [7]. Classical solar and wind energies, form most of the renewable resources available. They are free, non-polluted, and abundant in many parts of the world. Solar energy that is available within the Arab world in general, and specifically in the deserts of North Africa can, significantly, contribute to the overall world energy requirements. The main problems that are associated with utilization of solar and wind energies are the requirement for huge land area, variation of wind speed and solar radiation, and the high initial cost. This makes the arid sunny land of the Arab world a suitable place to apply this technology [8] [9] [10] [11] [12]. A success story is the utilization of solar energy available in Ma'an governorate, the Hashemite Kingdom of Jordan, that has the potential to contribute between $15 \%$ to $20 \%$ to the national power grid. Problems associated with the seasonal variations in the renewable energy sources can be overcome by applying hybrid systems.

Bioenergy is considered as another source of energy of a renewable nature, because of the continuous production of several types of wastes. It gained momentum due to several advances in biotechnology during the last two decades. Biogas is the major product in any bioenergy production process [13]-[18]. Processes of biogas production involve several types of organic wastes starting materials. Municipal wastes are difficult to be characterized and, therefore, it is a challenge to synthesize an optimum bioprocess to handle the waste as a source of biogas. Wide utilization of bio-wastes from different bio-sources has an advantage of environmental pollution reduction and low-cost energy production.

Biomass wastes are utilized to produce biogas through landfill burial processes. As a result, underground water pollution, odor problems, requirements of huge landfill areas are consequent problems associated with landfill. Hence, this will reduce land areas allocated for agriculture, and widespread diseases around the landfill due to possible irresponsible behavior of people. Moreover, landfill biogas production depends on natural parameters that lead to long waste retention times, and therefore, the product of the biological process cannot be utilized for any other useful process, such as natural fertilizers production.

Underground waste burial simulation shows a promising future for biogas production using municipal wastes, in which design models of different waste/sludge ratios, were tested [11]. Samples were incubated at underground temperature (2 $\mathrm{m}$ below earth: about the atmospheric temperature $20^{\circ} \mathrm{C}-30^{\circ} \mathrm{C}$ during SpringSummer seasons) and only under the effect of natural parameters. Results showed a retention time of buried samples was found to take months at these conditions [11].

In a recent review study, Yue et al. discussed the enhancement of methane 
production in anaerobic digestion process [19]. They concluded that many of the strategies of methane enhancement are not economically feasible, such as electrical pretreatment, thermal and radiant treatment, and chemical additives to enhance acidification [19]. On the other hand, utilization of solar energy (free source of energy) to enhance methane production is yet to be investigated. Methanogens will be more active at mesophilic temperature $\left(37^{\circ} \mathrm{C}-40^{\circ} \mathrm{C}\right)$, which will enhance methane production. Hence, the problem is: how to design a wellcontrolled heating system to provide an environment of mesophilic temperature for anaerobic bacteria? And how such utilization of solar energy affect biogas production from biomass landfill burial? Moreover, what will be the resulting biogas produced potential contribution to power mix in Jordan?

This study takes into consideration the above points regarding bioenergy production and biological wastes of various sources. It consists of a design of a bioreactor that simulates underground burial of wastes that is heated by a cascade control hybrid system of solar and electrical sources. The process temperature is controlled at a setpoint of $40^{\circ} \mathrm{C}$ to assure mesophilic biogas bacteria conditions. Biogas production at $40^{\circ} \mathrm{C}$ is compared to non-heated process (room temperature) with respect to the time required to start producing the gas, the retention time, and ratio of the volume of gas produced per $1 \mathrm{~kg}$ of the starting sample at STP. Sheep manure was used as a representation of biomass sources for the above design, and the results were used to estimate the possible biogas production from sheep manure in Jordan for the period of 2010-2016, which is compared to the energy produced from the established landfills around the country. Based on the results, the level of biomass utilization in Jordan was evaluated in addition to its potential to contribute to the national power mix.

\section{Materials, Experimental Design, and Procedure}

\subsection{Manure}

Dry sheep manure was obtained from a nearby farm at Mutah area (Al-KarakJordan). Manure samples were grinded and sieved to obtain particles of less than $100 \mu \mathrm{m}$ in size.

\subsection{Soil}

Soil samples were obtained from the area around engineering labs of Mutah University. They were collected from layers at $1 \mathrm{~m}$ depth, to make sure that they contain enough moisture. Samples were used immediately after collection to maintain their original properties.

\subsection{Sludge and Wastewater}

Sludge mixed with wastewater was used as a seeding material in the bioreactor, which was obtained from the bottom of the main pool of the wastewater treatment station at Mutah University and kept at $5^{\circ} \mathrm{C}$ before it was used. 


\subsection{Bioreactor}

A cylindrical bioreactor of 38 liters was made of galvanized steel sheet $(1.5 \mathrm{~mm}$ thick). A longitudinal section is shown in (Figure 1) with all internal parts of the reactor. It is heated with a water jacket of $5 \mathrm{~cm}$ thickness, connected to a constant flow pump set at 10 liters/minute. The water jacket and the rest of the reactor body is wrapped with a $5 \mathrm{~cm}$ thickness layer of glass wool.

The working space of the reactor consists of the sample space wrapped around by an $8 \mathrm{~cm}$ thickness layer of soil, collected from layers at $1 \mathrm{~m}$ depth, to make sure that they contain enough moisture. Samples were used immediately after collection to maintain their original properties.

\subsection{The Temperature-Controlled Bioprocess}

The flow sheet of the bioprocess is depicted in Figure 2. It consists of the reactor that is connected through a stainless tube pipe of $\left(\frac{1}{2}\right)^{\prime \prime}$ diameter to a water solar heater that provides hot water to heat the reactor through a constant flow pump, set at a constant flow rate 10 liters $/ \mathrm{min}$. and connected to a controller to stop when temperature at the exit of the reactor is at $40^{\circ} \mathrm{C}$.

The water solar heater is provided with an electric heater, that works when the temperature within the outlet header falls below $40^{\circ} \mathrm{C}$ and stops when the temperature reaches the $40^{\circ} \mathrm{C}$ set point. The constant flow pump works at temperature

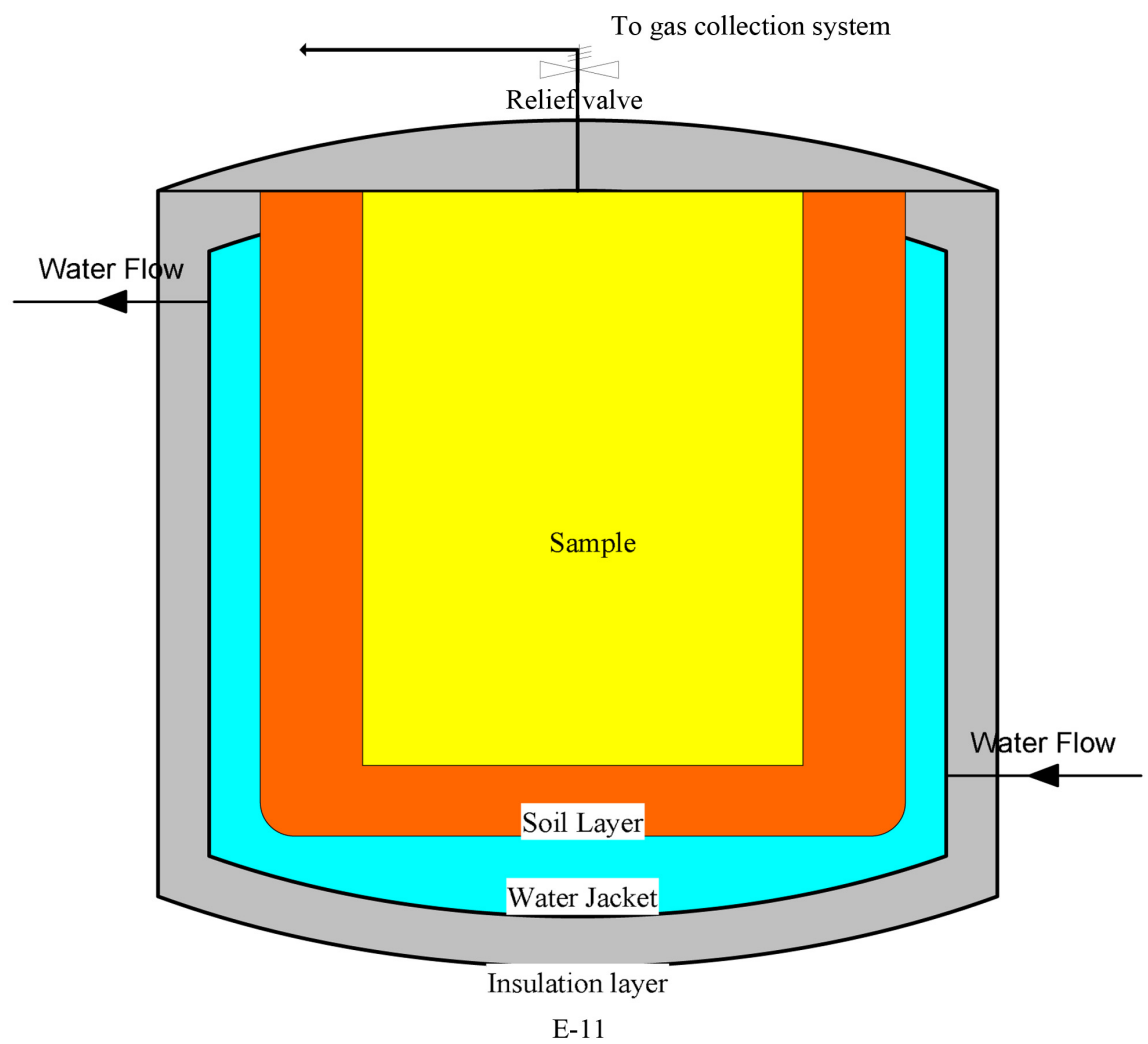

Figure 1. Longitudinal section of the bioreactor parts. 


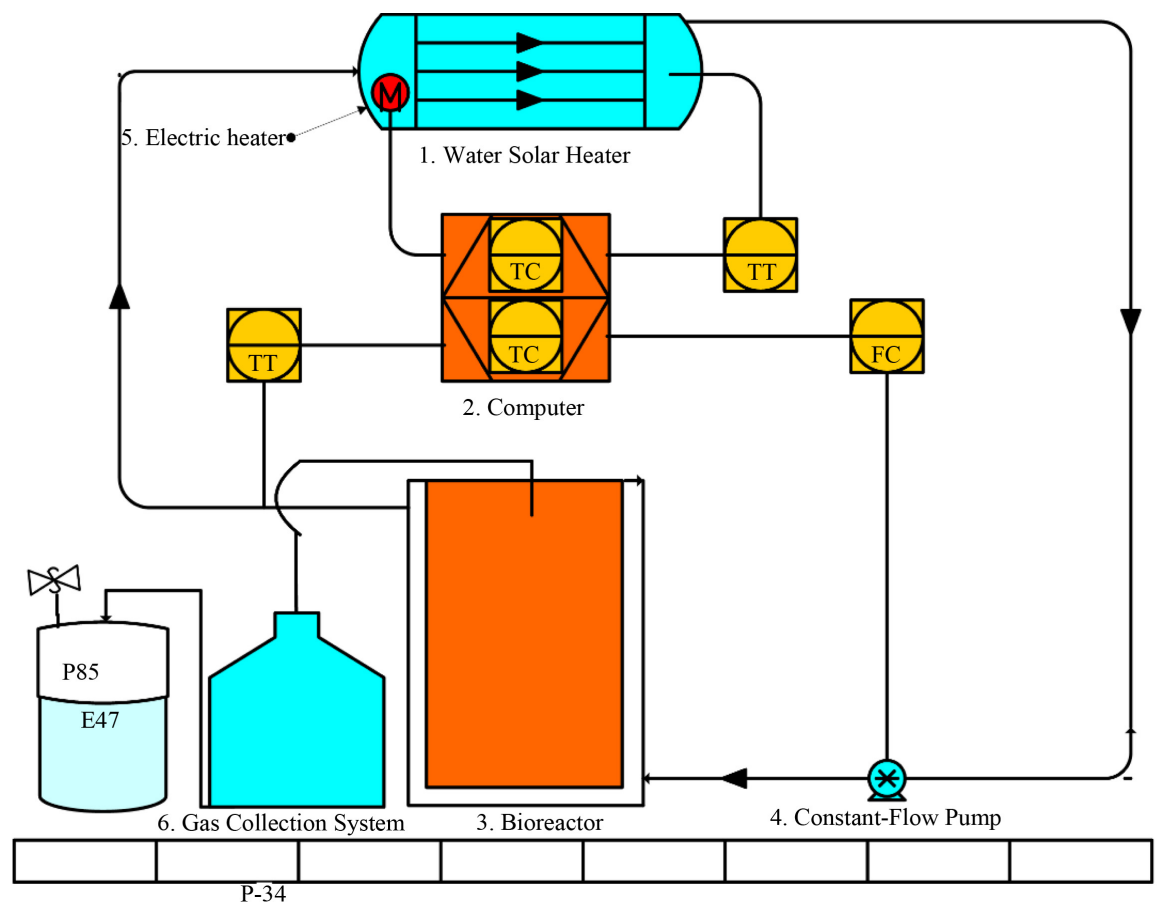

Figure 2. A pictorial flow sheet of the biogas production process.

below set point temperature until the temperature at the exit of the reactor reaches the set point temperature $\left(40^{\circ} \mathrm{C}\right)$. To achieve the heating requirements, two PID controllers are chosen to maintain uniform constant temperature within the reactor at $40^{\circ} \mathrm{C}$, and to keep the temperature in the solar water heater at a temperature $\geq 40^{\circ} \mathrm{C}$. The biogas is collected in a special system that is shown schematically in Figure 2.

\subsection{Dynamic Stability of the Control System}

The water jacket around the reactor with all internal components are approximated by a first order system whose transfer function is represented by:

$$
\frac{\bar{T}_{b o}(s)}{\bar{T}_{b i}(s)}=\frac{1}{1.63 s+1}
$$

$\bar{T}_{b o}, \bar{T}_{b i}$ : deviation temperature of bioreactor outlet and inlet temperaturs time constant $(\tau)=1.63 \mathrm{~min}$.

Also, the solar system is represented by another first order function of the form:

$$
\frac{\bar{T}_{s o}(s)}{\bar{T}_{s i}(s)}=\frac{1}{10 s+1}
$$

$\bar{T}_{s o}, \bar{T}_{s i}$ : deviation temperature of bioreactor outlet and inlet temperaturs time constant $(\tau)=10 \mathrm{~min}$.

We should note that outlet temperature of the bioreactor is an inlet temperature to the solar heater and the outlet temperature of the solar system is the inlet temperature of the bioreactor. Temperature measurement devices are thermo- 
couples that are linear and very sensitive to small changes in temperature within the range of set points temperature ranges. They are inserted, directly in water, therefore no lag is considered, and the gain of each one is equal to one. Moreover, the constant-flow pump (final control element of the outer loop/on-off type) and the thermistor (thermal resistor actuator/final control element of the inner loop) are considered to have a constant transfer function equal to one. A schematic of the cascade-control simulated applying Simulink software is shown in Figure 3. All components are shown to have a special transfer function for future modification of the system. The system dynamic stability is tested using Simulink (Matlab-R2015) and the corresponding tuning parameters of the two PID controllers are shown in Table 1.

The responses to a step function disturbance and a setpoint re shown in Figure 4(a) and Figure 4(b). It is evident that the system is dynamically stable and the response to any variation is instant which keeps the bioreactor at, almost, constant temperature.

\subsection{Solar Water Heater}

A controlled solar water heater was used to provide the reactor with heated water at steady $40^{\circ} \mathrm{C}$.

Table 1. Tuned parameters of the inner-loop and outer-loop controllers.

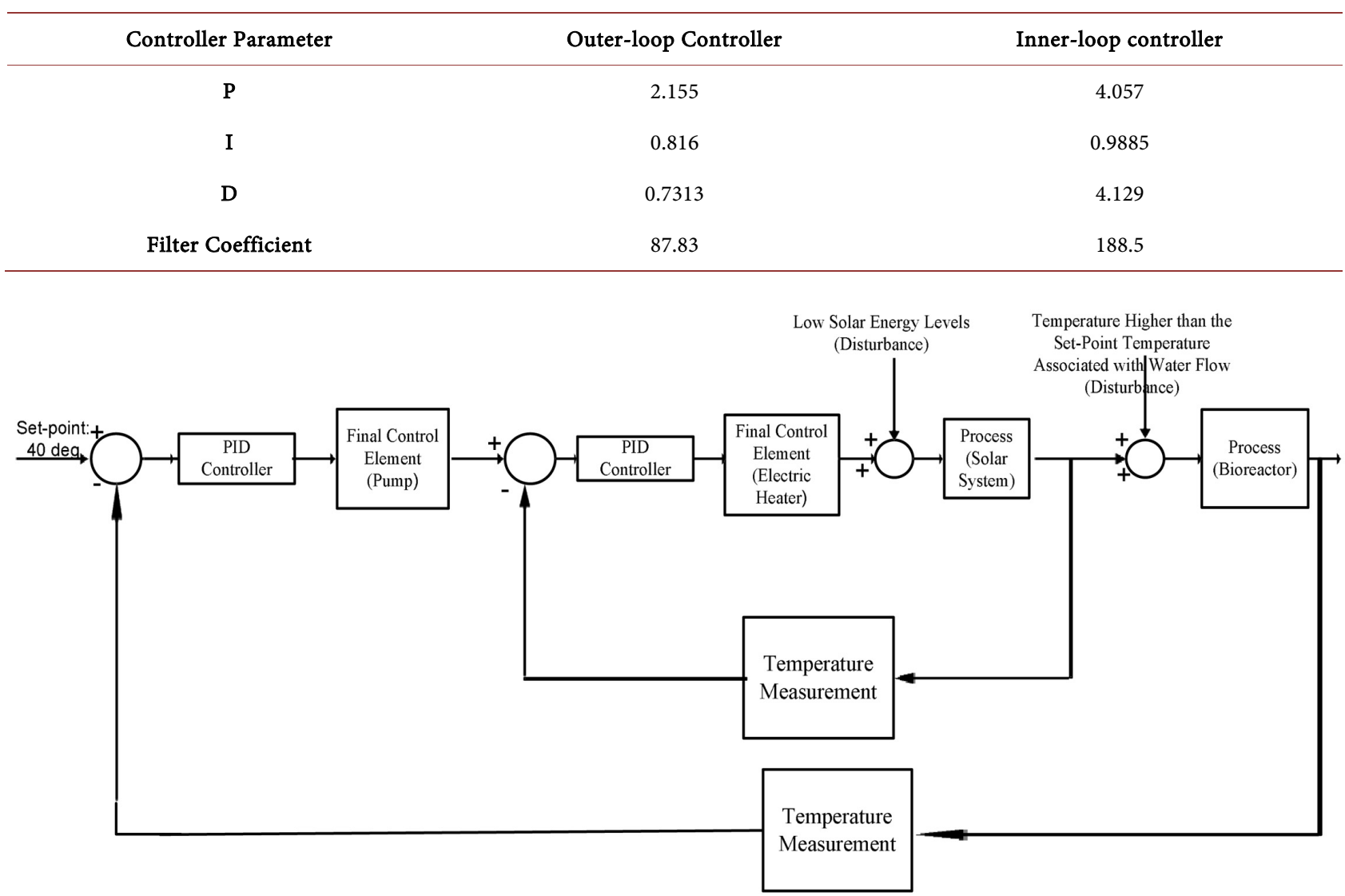

Figure 3. Block diagram of the solar-electric control system. 


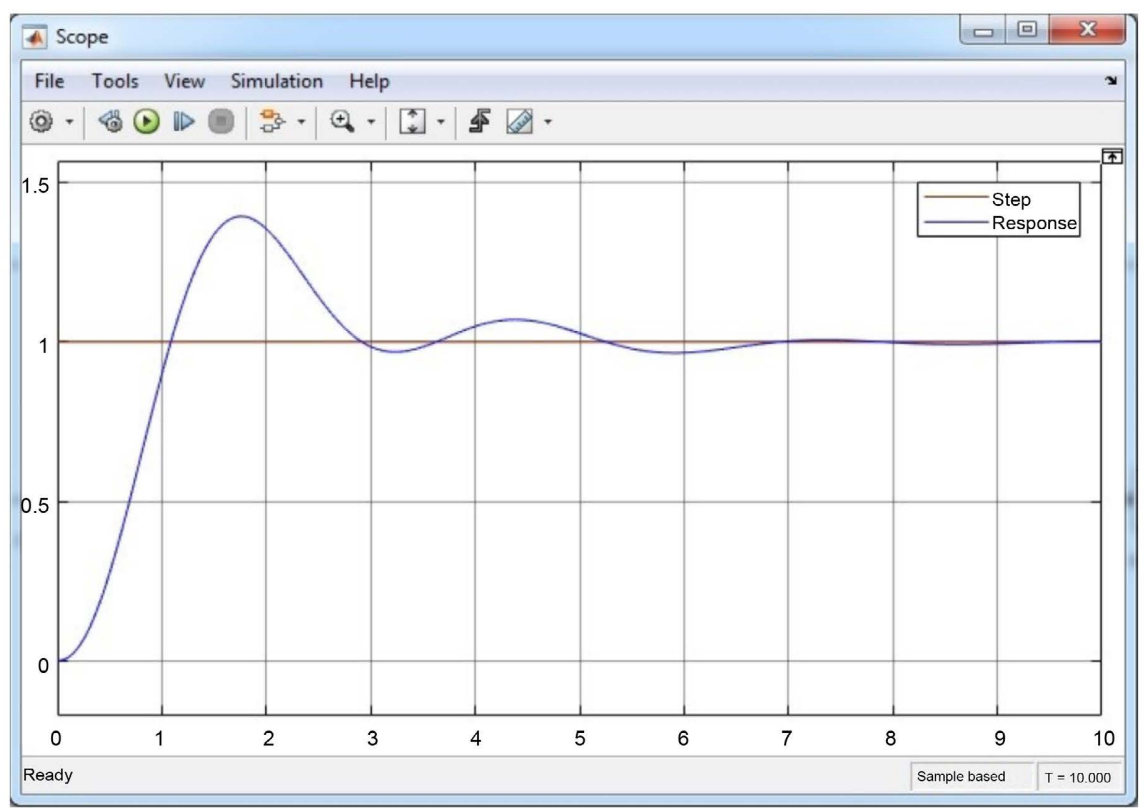

(a)

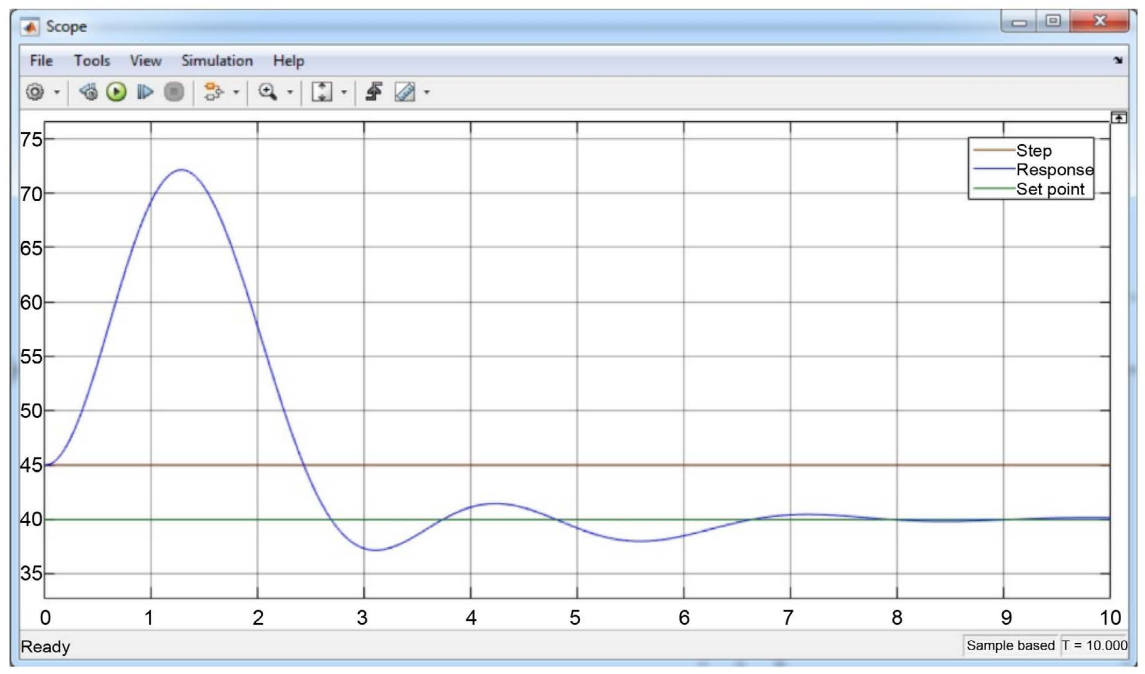

(b)

Figure 4. Response of a step change: (a) Unit step change, (b) $5^{\circ} \mathrm{C}$ change in setpoint.

\subsection{Insulation Material}

A $5 \mathrm{~cm}$ thick layer of rock wool was wrapped over the coil and covered the outer surfaces of the bioreactor base and lid.

\subsection{Sample Holder}

A steel cylinder ( $10 \mathrm{~cm}$ diameter, $37 \mathrm{~cm}$ height) was used to hold the 2.9 liters of manure sample in place while filling the rest of the reactor space by soil as described below in the experimental procedure section.

\subsection{The Total System}

The bioreactor was then connected to the controlled solar water heater, as shown 
in Figure 5.

\subsection{Sample Preparation}

A 1.45 liter ( $365 \mathrm{gm})$ of treated dry manureis mixed well with equivalent sludge and wastewater mixture. The final mixture $(\mathrm{pH} \approx 7.2)$ was kept in a closed container and then used within half an hour after preparation.

\subsection{Bioreactor Content Layout}

A soil layer of $8 \mathrm{~cm}$ thickness was distributed at the bottom of the reactor. The sample holder was then placed at the center of the layer. The mixture, manure/(sludge + wastewater), was transferred to the sample holder. The soil was then distributed around the sample holder to make a layer of $8 \mathrm{~cm}$ thickness. The sample holder was removed slowly and gently to leave the sample surrounded from all sides by soil. Another $8-\mathrm{cm}$ soil layer was added above the sample. A mixture of sludge and wastewater was slowly added after to the reactor until the soil was fully saturated. Finally, the top cover was placed, and heating water $\left(40^{\circ} \mathrm{C}\right)$ started to flow through the jacket. Figure 6 shows a cross-section

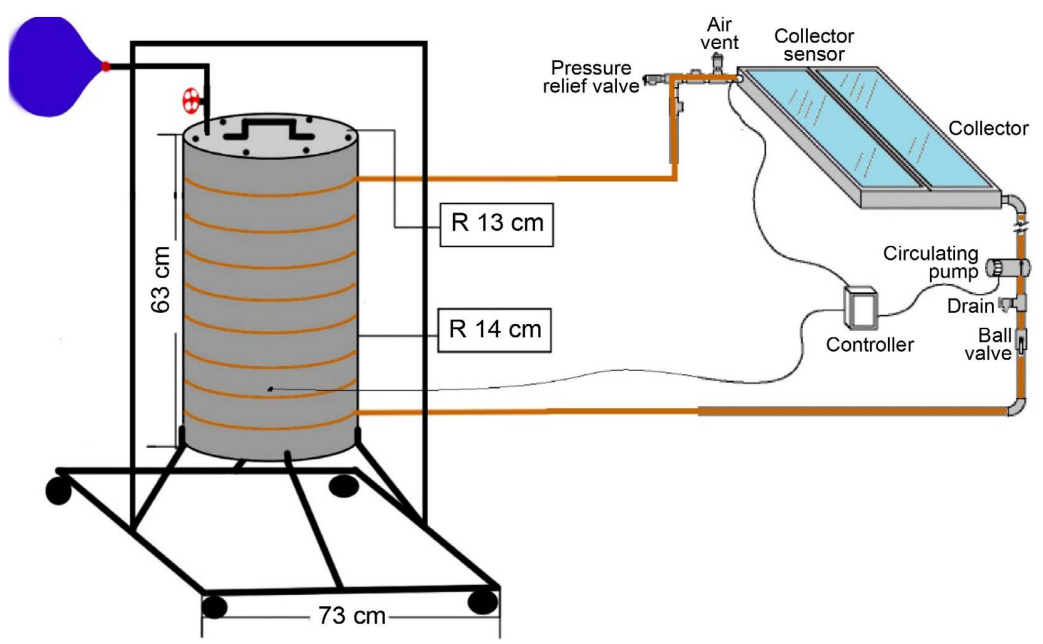

Figure 5. The total bioreactor system.

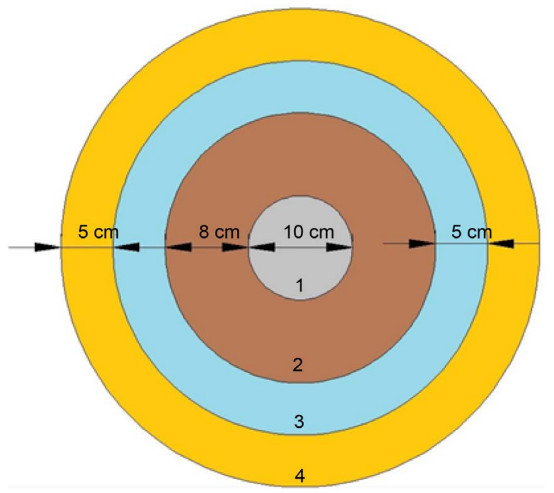

Figure 6. Cross-section through the reactor showing the four different layers. 1: sample; 2: soil; 3: heating tubes; 4: insulation. 
through the bioreactor with the dimensions of all layers. Experiments and controls were done in triplicates.

\subsection{Control Experiments}

The above procedure was carried out without heating, to measure the effect of utilizing solar heating on the production of gas from buried bio-waste.

\subsection{Biogas Analysis}

Produced biogas was analyzed in the laboratories of the Jordanian Petroleum Refinery Company.

\subsection{Estimation of Biogas Production from Sheep Manure in Jordan}

The number of sheep was obtained from the yearly statistical book of Jordan [20]. The biogas rate of production obtained from this study was used to obtain the yearly estimation of biogas and the corresponding estimated energy.

\section{Results and Discussion}

\subsection{The Proposed System}

Ten different experiments were carried out during one year. The year was divided into three parts, four months each. Three experiments were carried out in the first part, four in the second part, and three in the last part of the year. The first batch of experiments was reported as run number 3, the second batch was number 1 , and third batch was number 2. Solar energy was utilized for heating the materials within the reactor for the three batches of runs. The distribution of experiments over the year was to correlate any effect of weather conditions on the rate of production of the biogas. A control run was done using the same materials, used in the above three batches, at room temperature $\left(25^{\circ} \mathrm{C} \pm 2^{\circ} \mathrm{C}\right)$. Figure 7

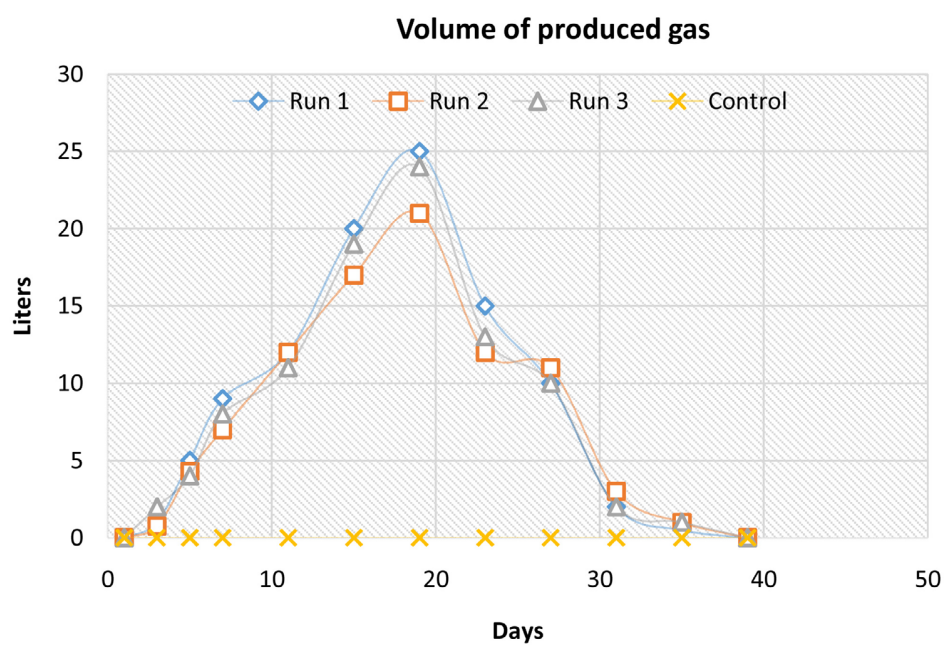

Figure 7. Results of the volume of biogas produced from buried sheep manure at $40^{\circ} \mathrm{C}$ compared to runs at room temperature. 
shows the results of bioreactor runs compared to results from the controlled experiments (room temperature).

The heating process control system appears to overcome any disturbance produced by the weather condition changes throughout the year. However, running the experiments within the middle six months avoids dependence on any other source of energy other than solar energy.

The results indicate that utilization of solar energy significantly affects the biogas production of manure soil burial process. Produced biogas was detectable at day 3 after starting. Maximum gas production was noticed around day 19, which is the time required for the methanogens to reach their maximum activity, after which such activities start to decay until they stop biogas (methane) production. Hence, no appreciable production of biogas was noticed after day 35, which indicates a 35-day bioreactor retention time. Runs of samples at room temperature did not show any appreciable amount of gas. The results reported do not show any significant variation of biogas production with respect to the time of the year.

Biogas produced was analyzed in the laboratories of Jordanian Petroleum Refinery Following their Standard Procedures. The results are shown in Table 2 below.

Results show a significant production of biogas from sheep manure at $40^{\circ} \mathrm{C}$ temperature. An average of 94 liters/sample of biogas was produced, with an average $\mathrm{CH}_{4}$ concentration of $65 \%$. Control samples, at room temperature, did not show appreciable amounts of biogas during the testing period of 39 days. After 35 days, none of the samples show any appreciable amounts of biogas, which indicates that this period is the retention time of the process. The equivalent amount of gas produced, on $\mathrm{kg}$ basis, is about 258 liters $/ \mathrm{kg}$ (STP conditions). This value makes about $95 \%$ of the value reported in [12]. Other investigators reported a range of values between 93 to 273 liters/ $\mathrm{kg}$ [13] [14] [15] [16] [17]. The variation in the reported results is due to different reasons; some are related to the process conditions such as pressure and temperature, others are related to the environment of the animals or the type of food intake.

The energy that we can get from the process described here does not require mixing. The mixing requires extra energy at an additional cost, and this reduces the economic potential of the production of biogas. The only source of energy employed for the process is solar, which is free except for the initial cost of building the system, which can be paid back in a short period. Moreover, in a

Table 2. Biogas analysis on volume percent.

\begin{tabular}{cccc}
\hline Biogas component & Run 1 & Run 2 & Run 3 \\
\hline $\mathrm{CH}_{4}$ & $63 \%$ & $67 \%$ & $66 \%$ \\
$\mathrm{CO}_{2}$ & $9 \%$ & $8 \%$ & $8 \%$ \\
$\mathrm{~N}_{2}$ & $22 \%$ & $20 \%$ & $20 \%$ \\
$\mathrm{O}_{2}$ & $6 \%$ & $5 \%$ & $6 \%$ \\
\hline
\end{tabular}


country like Jordan where sunny days are more than 300 days a year [21], the proposed system seems to be feasible.

Jordan is a non-oil producing country; therefore, the proposed system can be applied to produce bioenergy which will contribute to the reduction of the energy bill of the country. Biogas production has a high potential, as will be seen below, and can contribute to the national energy mix, and therefore help in decreasing energy cost. Limited studies are done showing the potential of biomass and biowaste [22] [23]. The industrial experience with respect to biogas production plants is also limited. Only two major plants that use municipal wastes are running, one in Rusifah area near Amman City and the other in Al-Khirbah Alsamra in the northern part of the country, in addition to some small household systems. Therefore, good campaign must be initiated through applied research to convince private and public sectors to invest in such good and cheap processes.

The results of this study indicate that burial of biowaste and biomass is feasible to be used as a source of biogas production, which in turn can take part in the production of electricity to the national grid. The process described above can be scaled up to handle municipal waste as well as wastes from animal farms distributed all over the country. The southern and the eastern parts of the country make more than $50 \%$ of the area of Jordan. People in these areas raise cattle at large scale; such as sheep, cows, and camels, that produce tons of wastes every year. Investment in such areas can be very beneficial, since the cost of the above pilot system was about $300 \mathrm{JD}$, however, it gave satisfactory results which can be employed as a reference point to scale-up the process.

\subsection{Biomass Potential}

To estimate the potential contribution of biogas obtained from sheep manure and consequently the total biomass to the power grid in Jordan, data on sheep number in Jordan (2010-2016) were obtained as mentioned above. Hence, estimation of manure production was based on an average value of $0.42 \mathrm{~kg} / \mathrm{head} /$ day of which $30 \%$ is solid, for the type of sheep (Awassi) in Jordan [24] [25], and biogas was estimated based on the results obtained and reported above (258 liters/kg at STP conditions). Moreover, the results of sheep number and the consequent estimated dry manure and biogas produced are depicted in Table 3.

Over the seven years period (2010-2016), the average number of sheep was about 2.5 million sheep per year. Consequently, the estimated average solid manure for this period (2010-2016) is about $115 \times 10^{6}$ ton which can produce $30 \mathrm{x}$ $10^{6} \mathrm{~m}^{3} /$ year of biogas. Moreover, the power obtained from the estimated biogas was calculated based on the results obtained from the proposed system above. Hence, results indicate a value of $6.5 \mathrm{kWh} / \mathrm{m}^{3}$ of biogas or $23,400 \mathrm{~kJ} / \mathrm{m}^{3}$ (STP), which agrees with results reported by Swedish Gas Center [18].

Based on the above results, estimated power from sheep manure was calculated and compared to the total yearly power production in Jordan, and to the yearly power obtained from utilized biomass in Jordan (Table 4). Moreover, the 
Table 3. Results on the number of sheep, estimated dry manure, and corresponding biogas production.

\begin{tabular}{cccc}
\hline year & Number of Sheep $(\times 1000)$ & $\begin{array}{c}\text { Estimated dry } \\
\text { manure (ton) }\end{array}$ & $\begin{array}{c}\text { Estimated biogas } \\
\text { production }\left(\times 1000 \mathrm{~m}^{3}\right)\end{array}$ \\
\hline 2010 & 2175.70 & $100,060.44$ & $25,815.59$ \\
2011 & 2264.60 & $104,148.95$ & $26,870.43$ \\
2012 & 2234.00 & $102,741.66$ & $26,507.35$ \\
2013 & 2311.10 & $106,287.49$ & $27,422.17$ \\
2014 & 2680.30 & $123,267.00$ & $31,802.89$ \\
2015 & 2596.40 & $119,408.44$ & $30,807.38$ \\
2016 & 3198.90 & $147,117.41$ & $37,956.29$ \\
Average & 2494.43 & $114,718.77$ & $29,597.44$ \\
\hline
\end{tabular}

yearly generated biomass power was compared to the estimated biogas power generated from sheep manure and shown in Table 4.

The yearly average power produced from the utilization of biomass is 5.80 GWH, which accounts to $0.04 \%$ of the average total national power. However, the average estimated power from biogas generated from sheep manure alone per year is $125.05 \mathrm{GWH}$, which, if utilized, accounts for $0.73 \%$ of the total power production, and about 22 times the power obtained from the utilized biomass. Therefore, biogas from different utilized sources of biomass can contribute to energy mix in Jordan, which will reduce the energy bill and the cost of biowaste disposal.

\subsection{Sustainability of Sheep Manure Biogas Production}

A recent study from our laboratory predicted the number of sheep in Jordan for the years 2017-2030 applying a linear regression model [26]. The linear regression equation used in reference [26] is:

$$
y=97761.49 x+1.4884090 \times 10^{6}
$$

The forecast of sheep numbers (2017-2030) was plotted according to Equation (3) above and compared to exact sheep numbers (2002-2016) and shown in Figure 8.

Forecasting of sheep number, based on the above model, between 2020-2030 are shown in Table 5 along with estimated values of dry sheep manure, biogas, and electric power.

Forecasted data indicate that sheep manure represents a sustainability source of energy, which will continue to contribute to the energy mix in Jordan. Moreover, predicted average of energy production over the years 2020-2030 increases by $150 \%$ over the average estimated vales for the years $2010-2016$. Furthermore, this may indicate that biomass is likely to be a potential source of energy that can be an added value to the energy sector in Jordan as well as to countries of similar conditions. 
Table 4. Estimated power from manure biogas compared to total electric power produced in Jordan and the contribution of biomass power contribution to the total power.

\begin{tabular}{|c|c|c|c|c|c|c|}
\hline Year & $\begin{array}{c}\text { Estimated } \\
\text { electric power } \\
\text { from CH4 } \\
(65 \% \text { of biogas }) \\
(\mathrm{GWH} / \mathrm{yr})\end{array}$ & $\begin{array}{c}\text { Total Electric } \\
\text { power } \\
\text { produced } \\
\text { in Jordan } \\
(\mathrm{GWH} / \mathrm{yr})\end{array}$ & $\begin{array}{l}\text { Electric } \\
\text { power } \\
\text { produced } \\
\text { from biogas } \\
\text { in Jordan } \\
(\mathrm{GWH} / \mathrm{yr})\end{array}$ & $\begin{array}{l}\text { Contribution of } \\
\text { utilized biomass } \\
\text { to total power } \\
\text { production\% }\end{array}$ & $\begin{array}{c}\text { Estimated } \\
\text { contribution of } \\
\text { manure biogas } \\
\text { to total power } \\
\text { production \% }\end{array}$ & $\begin{array}{c}\text { utilized } \\
\text { biomass } \\
\text { power to } \\
\text { estimated } \\
\text { manure } \\
\text { power \% }\end{array}$ \\
\hline 2010 & 109.07 & $14,777.00$ & 9.00 & 0.06 & 0.74 & 8.25 \\
\hline 2011 & 113.53 & $14,647.00$ & 8.00 & 0.05 & 0.78 & 7.05 \\
\hline 2012 & 111.99 & $16,596.00$ & 6.00 & 0.04 & 0.67 & 5.36 \\
\hline 2013 & 115.86 & $17,261.00$ & 6.00 & 0.03 & 0.67 & 5.18 \\
\hline 2014 & 134.39 & $18,266.00$ & 3.50 & 0.02 & 0.74 & 2.69 \\
\hline 2015 & 130.16 & $19,009.00$ & 4.00 & 0.02 & 0.69 & 3.07 \\
\hline 2016 & 160.37 & $19,730.00$ & 4.10 & 0.02 & 0.81 & 2.49 \\
\hline Average & 125.05 & $17,183.71$ & 5.80 & 0.04 & 0.73 & 4.87 \\
\hline
\end{tabular}

Table 5. Predicted production sheep manure and the associated biogas production.

\begin{tabular}{|c|c|c|c|c|}
\hline Year & $\begin{array}{c}\text { Linear Regression } \\
\text { Model }^{*}\end{array}$ & $\begin{array}{l}\text { Estimated Dry } \\
\text { Sheep Manure } \\
\text { Based on } \\
\text { Predicted } \\
\text { Sheep Number } \\
\text { (ton) }\end{array}$ & $\begin{array}{c}\text { Estimated Biogas } \\
\text { Production Based } \\
\text { on Estimated Dry } \\
\text { Manure (X1000 } \\
\left.\mathrm{m}^{3}\right)\end{array}$ & $\begin{array}{c}\text { Estimated Electric } \\
\text { Power Based on } \\
\text { Estimated Dry } \\
\text { Manure and 65\% } \\
\mathrm{CH}_{4} \text { Composition } \\
\text { (GWH/yr) }\end{array}$ \\
\hline 2020 & 3243.797 & $149,182.224$ & $38,489.01$ & 162.62 \\
\hline 2021 & 3341.558 & $153,678.254$ & $39,648.99$ & 167.52 \\
\hline 2022 & 3439.320 & $158,174.327$ & $40,808.98$ & 172.42 \\
\hline 2023 & 3537.081 & $162,670.355$ & $41,968.95$ & 177.32 \\
\hline 2024 & 3634.843 & $167,166.430$ & $43,128.94$ & 182.22 \\
\hline 2025 & 3732.604 & $171,662.458$ & $44,288.91$ & 187.12 \\
\hline 2026 & 3830.366 & $176,158.532$ & $45,448.90$ & 192.02 \\
\hline 2027 & 3928.127 & $180,654.561$ & $46,608.88$ & 196.92 \\
\hline 2028 & 4025.889 & $185,150.635$ & $47,768.86$ & 201.82 \\
\hline 2029 & 4123.650 & $189,646.664$ & $48,928.84$ & 206.72 \\
\hline 2030 & 4221.412 & $194,142.738$ & $500,88.83$ & 211.63 \\
\hline Average & 3732.604 & $171,662.471$ & $44,288.92$ & 187.12 \\
\hline
\end{tabular}

${ }^{*}$ Data were adapted from reference [26].

The above results indicate that biomass in Jordan is not fully utilized, as well as other sources of biomass, in power production. Hence, adding sheep manure and other biomass sources to the strategic energy plans of Jordan and similar developing countries may contribute to at least $15 \%$ of the power requirement, which eventually will reduce the cost of energy that represents a serious problem facing the household energy bill and consequently the national economy. The combination of biomass power and the oil shale power that is recently being 


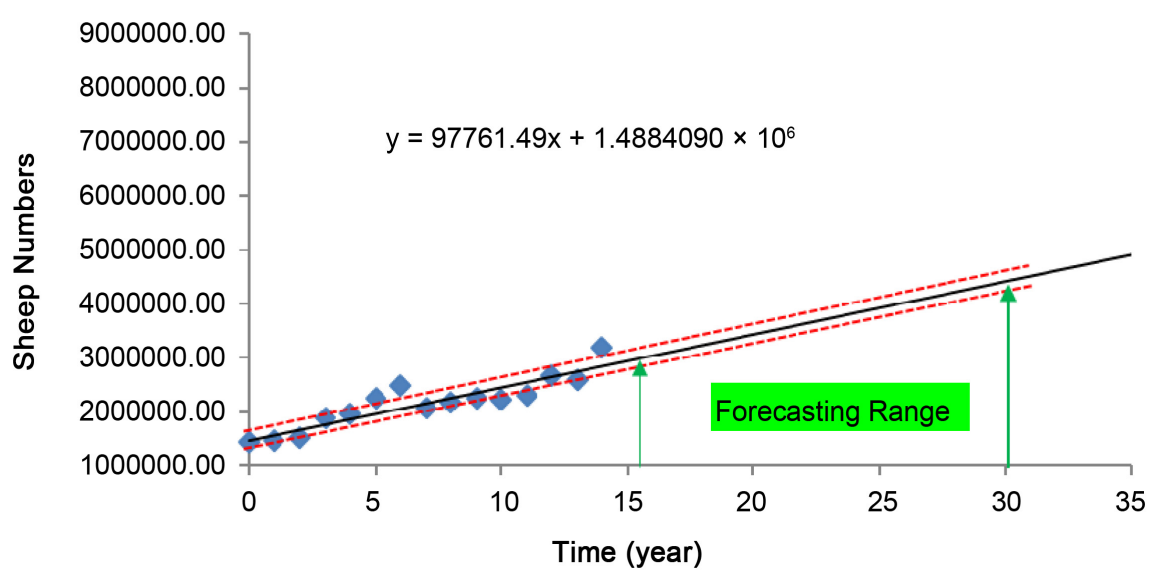

Figure 8. The results of the linear regression model showing the real data of sheep number compared to the predicted values and the forecasting sheep number ( ${ }^{*}$ Adapted from reference [26]).

utilized by Jordan is expected to produce about $15 \%$ to $20 \%$ of the power requirements [27]. Moreover, biomass and oil shale energy with the current utilization of solar and wind energies will lead to a total contribution of at least 50\% of the total power requirements coming from non-conventional sources of energy. This will help Jordan as a non-oil-producing country to reduce the power bill and the consequently the environmental pollution. Therefore, the results indicate that biomass is a possible potential source of energy. Moreover, the suggested burial system with the mesophilic controlled temperature can be considered as a possible candidate, upon scale-up to replace landfill burial of biowaste. Also, the bioreactor final products may be utilized to start organic fertilizer industry.

Based on the above, applying this technology to construct biogas production plants, will significantly decrease biowaste disposal areas. Therefore, future work will involve investigation on how to design a continuous biogas production process, which can be scaled-up. Moreover, the combined wind, solar, biomass, oil shale energies will help to solve many problems related to the energy sector of the country, and energy shortage problems as well as drinking water shortage problems will be minimized.

\section{Conclusions}

The above results of this research lead to the following conclusions:

- A well-controlled heating system was successfully designed and implemented to provide a non-mixed bioreactor with the required mesophilic temperature.

- Utilization of solar energy, a free source of energy, to heat the bioreactor reduced its retention time, and hence, biowaste burial can be replaced with bioreactor, which will eventually reduce landfill and consequently reduce environmental and underground water pollution.

- Applying the proposed system on sheep manure and forecasted sheep number indicates a biomass potential contribution to power mix in Jordan and 
possibly other countries with similar conditions.

\section{Acknowledgements}

The authors wish to thank Mutah University for granting the corresponding author (Taha M. Alkhamis) a sabbatical leave for a year in which this work was carried out, and Engineer Basel Al-Khamis for his help in figures preparations.

\section{Conflicts of Interest}

The authors declare no conflicts of interest regarding the publication of this paper.

\section{References}

[1] Alkhamis, T.M., El-Khazali, R., Kablan, M.M. and Alhusein, M.A. (2000) Heating of a Biogas Reactor Using a Solar Energy System with Temperature Control Unit. Solar Energy, 69, 239-247. https://doi.org/10.1016/S0038-092X(00)00068-2

[2] Alkhamis, T.M., Alhusein, M.A. and Kablan, M.M. (1998) Utilization of Waste Heat from Kitchen Furnace of an Enclosed Campus. Energy Conversion and Management, 39, 1113-1119. https://doi.org/10.1016/S0196-8904(97)00031-9

[3] Alkhamis, T.M., Alhusein, M.A. and Kablan, M.M. (1998) Performance Evaluation of Coil Heat Exchanger as Waste Heat Recovery Equipment. Renewable Energy, WREC.

[4] Alkhamis, T.M. and Alhusein, M.A. (1999) Cooked Waste Food as a Source of Biogas Production in an Enclosed Campus. Journal of Engineering-India, 9, 1-9.

[5] Kablan, M.M., Alhusein, M.A. and Alkhamis, T.M. (1999) Electricity Audit for Household Sector of the Capital City of Jordan, Amman. Energy Conversion and Management, 40, 1849-1861. https://doi.org/10.1016/S0196-8904(99)00033-3

[6] Alkhamis, T.M. and Kablan, M.M. (1999) Olive Cake as an Energy Source and Catalyst for Oil Shale Production of Energy and Its Impact on the Environment. Energy Conversion and Management, 40, 1863-1870.

https://doi.org/10.1016/S0196-8904(99)00023-0

[7] Linden, H.R. (2000) Electrification of Energy END-USE, an Assay on Its History, Economic Impact and Likely Future. Unpublished Notes, (Frank W. Gansaulus Professor of Chemical Engineering), Illinois Institute of Technology, Chicago.

[8] Kabariti, M. (2009) Jordanian Experience in Renewable Energy. A Lecture Given in the Scientific Day of the College of Engineering at Mutah University, April.

[9] Klass, D.L. and Emert, G.H. (1981) Fuels from Biomass and Wastes. Ann Arbor Science, Ann Arbor.

[10] Hessami, M., Christensen, S. and Gani, R. (1996) Anaerobic Digestion of Household Organic Waste to Produce Biogas. Renewable Energy, 9, 954-957. https://doi.org/10.1016/0960-1481(96)88438-2

[11] Alkhamis, T.M. (2009) Production of Biogas Using Anaerobic Digestion of Animal Wastes in Simulated Experimental Model of Underground Burial Process. Internal Report, Department of Chemical Engineering, Mutah University, Mutah.

[12] Song, L., et al. (2010) Biogas Production Potential and Characteristics of Manure of Sheep, Duck, and Rabbit under Anaerobic Digestion. Transactions of Chinese Society of Agricultural Engineering, 26, 277-282.

[13] Plūme, I., Dubrovskis, V. and Plūme, B. (2012) Specified Evaluation of Manure Re- 
sources for Production of Biogas in Planning Region Latgale. International Scientific Conference: Renewable Energy and Energy Efficiency, Jelgava, 28-30 May 2012, 103-108.

[14] Renè, A. and Lidèn, G. (2009) Low Temperature Anaerobic Digestion of Mixtures of Llama, Cow, Sheep Manure for Improved Methane Production. Biomass and Bio Energy, 33, 527-533. https://doi.org/10.1016/j.biombioe.2008.08.012

[15] Batzias, F.A., Sidiras, D.K. and Spyrou, E.K. (2005) Evaluating Livestock Manures for Biogas Production: A GIS Based Method. Renewable Energy, 30, 1161-1178. https://doi.org/10.1016/j.renene.2004.10.001

[16] Tatlid, I., Fusan, F., Bayramoglu, Z. and Akturk, D. (2009) Animal Manure as One of the Main Biogas Production Resources: Case of Turkey. Journal of Animal and Veterinary Advances, 8, 2473-2476.

[17] Gu, T.T.T., Nguyen, T.X., Triolo, J.M., Pedersen, L., Le, V.D. and Sommer, S.G. (2015) Biogas Production from Vietnamese Animal Manure, Plant Residue, and Organic Waste: Influence of Biomass Composition on Methane Yield. Asian-Australasian Journal of Animal Sciences (AJAS), 28, 280-289. https://doi.org/10.5713/ajas.14.0312

[18] Svenskt Gastekniskt Center (Swedish Gas Center) (2012) Basic Data on Biogas. 2nd Edition.

[19] Li, Y., Chen, Y. and Wu, J. (2019) Enhancement of Methane Production in Anaerobic Digestion Process: A Review. Applied Energy, 240, 120-137. https://doi.org/10.1016/j.apenergy.2019.01.243

[20] Statistical Yearbook of Jordan (2016) Department of General Statistics, Jordan.

[21] Alrwashdeh, S. (2018) Comparison among Solar Panel Arrays Production with a Different Operating Temperature in Amman-Jordan. International Journal of Mechanical Engineering and Technology (IJMET), 9, 420-429.

[22] Abu-Hamatteh, Z.S.H., Al-Jufout, S., Abbasi, B. and Besieso, M.S. (2010) Biogas Energy: Unexplored Source of Energy in Jordan. International Conference on Renewable Energies and Power Quality (ICREPQ10), Granada, 23-25 March 2010, 9-14. https://doi.org/10.24084/repqj08.202

[23] Alrousan, A. (2013) Biomass Potential in Jordan and Future Research Prospects. National Energy Research Center-Bioenergy Division, Oral Presentation.

[24] Sani, R.T. and Jokhtan, G.E. (2015) Manure Production by Yankasa Sheep Grazing Natural Pastures in Northern Guinea Savannah Zone of Nigeria. Journal of Animal Production Research, 27, 176-183.

[25] Standardized Calculation Methods for Animal Manure and Nutrients (2012) Standard Data Netherlands, 1990-2008, The Hague/Heerlen.

[26] Alma'atah, B.M. and Alkhamis, T.M. (2020) Sustainability of Sheep Fleece Utilization in Jordan as an Insulation Material to Decrease Environmental Pollution, Increase Farmers' Income, and Create New Job Opportunities. Journal of Environmental Protection, 11, 821-837. https://doi.org/10.4236/jep.2020.1110051

[27] Al-Atarat Oil Shale Power Company in Jordan (Report) (2019). 